\title{
Human Trafficking and Human Smuggling to and from Eastern Sudan: Intended and Unintended Consequences of States' Policies
}

\author{
Bahlbi Y. Malk \\ Post-War Reconstruction and Development Unit (PRDU), The University of York, York, UK \\ Email: bahlbi.y@gmail.com
}

\section{Doi:10.5901/ajis.2016.v5n1p215}

\section{Abstract}

\begin{abstract}
This paper argues that irregular migration and human trafficking business are symptoms and consequences of political and legal failures on the part of the origin and host states. The crisis has been created, sustained and enabled by state-imposed human insecurities and highly restrictive border and asylum policies in the countries of origin, transit and destinations. Therefore, any attempt to solely deal with the symptoms including border control and implementation of legal measures to punish irregular migrants and traffickers are more likely to fail and less likely to affect the demand for its service. In an effort to stem the flow and combat human trafficking network, EU States have over-criminalized smugglers and provided financial assistance to oppressive governments in the name of poverty eradication but only to sustain the root causes of migration and trafficking crisis they aspire to tackle. States' approach to over-criminalize human smugglers is leading to the transformation of smugglers into human traffickers jeopardizing refugees' lives in the process. This paper explores the nexus between States' migration policies and the surge of human trafficking business as well as the transformation of smugglers into human traffickers. Drawing from the Eritrean refugee experiences trafficked from Eastern Sudan to Egypt and Israel, this paper aims to shade some light on human trafficking and smuggling networks, and to fill the gaps in knowledge about the victims affected by the process.
\end{abstract}

Keywords: human trafficking, human smuggling, asylum-seekers, refugee protection

\section{Introduction}

Human trafficking is a growing transnational criminal phenomenon, which has been one of the most challenging consequences of contemporary human insecurity and threats to vulnerable people in the world. Despite the growing awareness creation, however, the phenomenon still remains to be poorly understood, less affected by the poorly developed strategies to tackle it, and complicated by variety of facilitators and contributing factors that are often overlooked. Without understanding the cause, complex nature and actors (victims and perpetrators) of the transnational clandestine crime syndicate, it would be nearly impossible to prevent the crime, protect the victims and prosecute the criminals. Drawing from the historical nature of the commonly practiced human trafficking where women and children had been the likeliest victims of the criminal network under the pretext of employment and economic opportunities, scholars, policymakers and practitioners have often cited poverty as a main cause of human trafficking and smuggling (Delport and Mackay 2007; Chuang 2006). Consequently, much attention has been paid on poverty as a root cause and consequence of refugee exodus and human trafficking.

Like in any parts of the world, human trafficking is not a new phenomenon in the Sub-Saharan African countries but it has been prevalent in the context of trafficking women and children for farm labor, domestic service and prostitution in, to and from African countries (Adepoju, 2005). Subsequently, African literatures on human trafficking have predominantly focused on how women and children from socio-economically disadvantaged family backgrounds have been the primary victims of human trafficking (ibid). In recent years, however, Eastern Sudan has witnessed the emergence of a new trend of human trafficking that involves the abduction of refugees from within and around refugee camps in Eastern Sudan to the Sinai Peninsula. This is a relatively new phenomenon in the Sub-Saharan African (SSA) countries since the end of slave trade. As most literatures and political debates have mainly focused on human trafficking in terms of commercial sex trafficking and forced labor (UNODC, 2016), little is known and written about the nature and victimization patterns surrounding human trafficking that specifically involve abduction, sexual violence, torture, extortion and killing of refugees. Furthermore, scholars have largely failed to recognize that the state-imposed human insecurity (lawlessness, oppression, violence, bad governance, corruption, deprivations and violations of fundamental rights) and highly restrictive border and asylum policies in the countries of origin, transit and destinations as one of the main creating, 
sustaining and enabling factors. There is a strong evidence to suggest that the recent increase in human smuggling and trafficking of asylum seekers and refugees to and from Eastern Sudan is largely the byproduct of the excessively oppressive government and tightly closed borders in Eritrea which was initially designed to keep the population in. This has further been exacerbated by the intended consequence of hostile and lawless refugee receptions in transit and countries of first asylum that was potentially aimed at discouraging potential arrivals of further asylum seekers by creating an environment of fear, disorder and insecurity to those who are already in their jurisdictions. The growing irregular migration to Europe and their dependency on illegal criminal network to cross the Saharan Desert and Mediterranean Sea to seek protection, on the other hand, is the unintended consequence of the restrictive migration policies in destination countries, which was envisioned to keep refugees out.

Arguably, the primary and secondary irregular migration and the clandestine criminal networks are the most significant manifestation of states' failed policies and approaches that breed insecurity, displacement, exploitation and vulnerability. While the absence of human security and the growing deprivations of fundamental rights in the country of origin have increased the desperation to leave, the highly restrictive border policies at home and hostile migration practices in the country of asylum have increased the demand for human smugglers/traffickers and created a fertile ground for them to practice with near impunity. Therefore, governments' attempt to impose generic migration control and the growing reluctance to secure refugee rights and protection enshrined in the Geneva Convention 'have inadvertently created a market where enterprising agents with appropriate social connections and resources have built a profitable business. The demand for their services continues to rise with governments' efforts to restrict illegal migration' (Zhang 2007:22). Consequently, at the center of the growing smuggling and trafficking activities are the very restrictions governments have imposed to curtail the outward and/or inward flow of refugees; and at the heart of illegal migration facilitation and surge are human traffickers and smugglers without whom neither evasion of the Eritro-Sudan border surveillance unit nor the crossings of the Saharan, Sinai and Mediterranean Sea would have been easy.

In addition to its oppressive political practices at home, Eritrea has a 'no-exit' and 'shoot-to-kill' policy in place where any citizens under the age of 60 are not allowed to leave legally and subjected to get shot at the border if they attempt to flee illegally. Thus, in the Eritrean context, the impetus of utter reliance on smugglers is more heightened by the absence of any legal way to exit. Subsequently, the services of clandestine transnational non-state actors have become the only venue to evade militarized border areas and migration laws in the countries of origin and asylum in their quest for freedom and protection. Under such circumstance, human smugglers and traffickers are the only 'service providers' who have the necessary information and knowledge about less militarized and less policed border crossings and the appropriate time to do so. Therefore, faced with this dilemma, asylum seekers with the help of human smugglers have to break national, regional and international border laws to 'avail themselves of the international protection afforded by the Geneva Convention' (Black, 2003:49).

With the growing number of refugees and asylum-seekers in Europe, however, the issue of human trafficking and smuggling have recently received much attention, albeit with more emphasis on the perceived and real threats that illegal migration and by association, human trafficking and human smuggling pose to state security (Kanter, 2015; HRW, 2015), much less on the primacy of the human rights of the victims who are most affected by the process. Although smuggling and trafficking are symptoms of insecurity and hostile migration policies at home, they are often portrayed as root causes of the migration problems in Europe. The source of the problem ultimately lies in the country of origin where political oppression is one of the main driving forces behind the growing desire to leave and the rise of the organized crime syndicate who benefit from people's socio-economic and political despair. However, in their effort to stem refugee flows and combat human trafficking, European States have consistently been funding the State of Eritrea in the name of poverty eradication (European Union Commission, 2015) only to sustain the root cause of the refugee crisis and trafficking business they aspire to tackle. As EU states are more preoccupied with border militarization, externalization and financial assistance to oppressive regimes to keep irregular migrants out of Europe and less on the origin of the problem, the human trafficking and smuggling businesses have become more lucrative and sophisticated to a point of undermining states' ability and rights to control who crosses their borders and/or who remains in their territories. Therefore, despite border closures, enforcements of regional confinement, externalization, criminalization of refugees and abandonment of legal resettlement processes, refugees are 'moving further, faster and in far greater numbers than ever' (Gallagher, 2001:977).

Furthermore, part of the Trafficking and Smuggling Protocols where states are required to 'increase commitment to border controls' and 'criminalize trafficking,' the majority of states have used it to justify strict border measures and criminalization of human traffickers and the trafficked/smuggled as deterrent mechanisms to 'prevent refugees from reaching their jurisdiction' (Hathaway, 2008:35-37). This has driven up the cost of the service and increased the risk and 
vulnerability of refugees to abuse and exploitation by smugglers and human traffickers for the poor cannot afford to pay the exorbitant prices often demanded. Consequently, the ever-growing cross-border trafficking/smuggling and abduction to and from Eastern Sudan has generated complicated problems to innocent and vulnerable refugees in or outside the refugee camps. This paper therefore stresses mainly on the insecurity in and around refugee camps that involve abduction of refugees from Eastern Sudan refugee camps to Sinai Peninsula in which case refugees are considered a prima facie trafficked. It also explores the nexus between States' migration policies and the surge of human trafficking business as well as the transformation of smugglers into human traffickers. Drawing from the refugee experiences trafficked from Eastern Sudan to Egypt and Israel, this paper aims to shade some light on human trafficking and smuggling networks, and to bridge the gaps in knowledge about the victims affected by the process. The subject however requires in-depth field research and close examination of the state and non-state actors, colluders and the victims but given the security issues involved, the author's investigation was restricted to secondary data analysis.

\section{Distinction between Human Trafficking and Human Smuggling}

As the nature, cause, motivation, act/ actors and victimization pattern varies from country to country, it is difficult to establish coherent definitions and clear distinction between human smuggling and human trafficking. With the growing anti-immigrants political attitudes and approaches in Europe, States have also developed vested interest in blurring the distinction to legitimatize the criminalization of all illegal migration facilitators, trumpeting the justification of military force against migrants under the guise of combating human trafficking scheme (Kanter, 2015; Nichols and Charbonneau, 2015). Smugglers face the same criminological definition and legal consequences as human traffickers. However, criminalization of human smugglers in line with human traffickers not only have created conceptual and legal confusions but also jeopardized the lives of asylum seekers who entirely depend on their service.

The relationship between asylum seekers and smugglers is not often as simple as 'service providers' and 'service receivers' contract. It involves a network of family members, members of ethnic communities, friends, and relatives who play significant roles in arranging the smuggling process, accommodation, material and financial assistance. It is also worth noting that not all human smugglers are paid migration facilitators as there are many family members, refugees, friends and benevolent individuals helping refugees and asylum seekers reach safety. But the over-criminalization of smuggling has sometimes led into criminal charges against fishermen, boat captains and other individuals who offer humanitarian assistance or 'involved in the rescuing or inadvertent transport of irregular migrants [which] has resulted in their reluctance to take responsibility for boats in distress, thus compounding the risk of death at sea' (Crépeau, 2013).

It is evident that with the shrinking resettlement opportunities and growing harsh migration and border policies, desperate people are increasingly depending on human smuggling service to reach safety. By criminalizing border entrance and exit, states have created a demand for human smuggling services; and by criminalizing human smugglers on equal footing with traffickers, states not only have created deterrence for good altruists and family members from helping the vulnerable but also created reasons for smugglers to exploit asylum seekers and engage in violent actions and crimes akin to human trafficking just to avoid getting caught. A case in point is the incident in May 2015 where human smugglers have thrown pregnant women and children overboard and took off (Gerver, 2015). Therefore, criminalization of people who support asylum seekers, and categorization of smugglers with traffickers have only increased the risks and costs of crossing borders and more likely have transformed many smugglers into human traffickers. Now human smuggling and trafficking are becoming closely interlinked and interrelated practices and play interchangeable roles.

In a narrow context, Article 3(a) of the United Nations Protocol against the Smuggling of Migrants by Land, Sea and Air defines human smuggling as 'The procurement, in order to obtain, directly or indirectly, a financial or other material benefit, of illegal entry of a person into a State Party of which the person is not a national or permanent resident.' ${ }^{1}$ Under Article 3(a) of the United Nations Protocol to Prevent, Suppress and Punish Human Trafficking in Person, especially Women and Children, human trafficking is defined as:

The recruitment, transportation, transfer, harbouring or receipt of persons, by means of the threat or use of force or other forms of coercion, of abduction, of fraud, of deception, of the abuse of power or of a position of vulnerability or of the giving or receiving of payments or benefits to achieve the consent of a person having control over another person, for the

${ }_{1}^{1}$ Protocol against the Smuggling of Migrants by Land, Sea and Air, supplementing the United Nations Convention against Transnational Organized Crime, UN General Assembly Resolution 55/25, Annex II, U.N. GAOR, U.N. Doc. A/45/49 (2001), which entered into force on 28 January 2004. 
purpose of exploitation. Exploitation shall include, at a minimum, the exploitation of the prostitution of others or other forms of sexual exploitation, forced labour or services, slavery or practices similar to slavery, servitude or the removal of organs. $^{2}$

The general consensus on the definition and practice of the two transnational clandestine illicit activities is that human trafficking involves in coercion, deception and exploitation before and after migrants reach their destination, while human smuggling is based on consented contract between the smugger and the smuggled to facilitated illegal exit or entry which ends upon destination (Zhang, 2007). In theory, human trafficking can easily be distinguished from human smuggling in its coercive and exploitative manner, which is the main basis for the dichotomy. However, contrary to widespread perception, several empirical studies have shown that both are becoming mutually interdependent practices that are not as clear as the definitions suggest (Aronowitz, 2001). In the context of Eastern Sudan, the conceptual and practical distinction is even getting further complicated for there is no clear dichotomy between the concepts, practices, natures, causes and motivations of human smuggling and trafficking. What is seemingly a voluntary and verbal contract between smugglers and smuggled often changes to exploitative and abusive operation during the smuggling process, which is a clear characteristics of trafficking. Van Reisen, Estifanos and Rijken (2013) note that, human trafficking from Eastern Sudan starts either as a consented human smuggling process which 'evolves into trafficking or it can start straight away as trafficking' which involves coercion, abduction and deception (p.23). As many refugees have depended on smugglers for border crossing, the practice has increasingly become expensive and many refugees cannot afford to pay the excessive prices charged by smugglers, which make them vulnerable for exploitation, extortion and abuse upon arrival that amount to trafficking. There are also plenty of evidence to suggest that smugglers have often been selling refugees to higher bidder human traffickers (UNHCR 2013) without the knowledge and consent of refugees exposing them to torture, rape and death. Consequently, families, friends and relatives in the state of origin have become so indebted to the human smugglers/traffickers and forced to sell whatever properties they have to save the member(s) of their family or community that sometimes takes the entire villages to raise the ransom money demanded by the human traffickers/smugglers (Van Reisen, et al. 2013), which has become a threat to the socioeconomic security of survivors and their families. Although a significant number of smugglers have been transformed into human traffickers for they can involve in ruthless and deceptive practice that goes beyond a voluntary and consented facilitation of illegal migration, it would be misleading to suggest that all smugglers are traffickers.

\section{Abduction of Refugees from Eastern Sudan}

Human smuggling has been one of the enabling factors in the Eritrean migration history since the 1960s when Eritreans had begun flocking to Sudan in their attempt to flee war and oppression during the Ethiopian consecutive regimes. Given the geographical proximity to Sudan and the Sudanese open-door policy, however, the Eritrean lowlanders had hardly relied on smuggling service comparing to the highlanders who had depended entirely on consensual smuggling service to trek across provinces and military guarded terrains to reach refugee camps in Sudan. The contemporary human insecurity and punitive emigration practices at home and the hostile reception and immigration policies as deterrence mechanisms in the country of asylum, however, has led asylum seekers from most regions and ethnic backgrounds to routinely rely upon illicit clandestine smuggling network to flee to safety. As stated earlier, however, not all human smugglers involve in material and benefit-driven services, as there are many family members, refugees, friends and benevolent individuals helping refugees and asylum seekers reach safety. Therefore, for the most part, a great majority of Eritrean asylum seekers have been seeking exit from Eritrea and entry into Sudan through voluntarily smuggling services until recent reports of abduction by human traffickers from within Eritrea came to light.

Academic researchers from Tilburg University and the UN Monitoring Group on Somalia and Eritrea have presented an investigative report citing the abduction of Eritreans from Eritrea to Sudan and/or to Sinai where they have been exposed to extortion and horrific violence (Van Reisen, et al 2013; UNMGSE, 2013). According to UNMGSE, highlevel government officials along with the chain of 'intermediaries' have directly been responsible for many of the human trafficking operations from Eritrea. Van Reisen et al. (2013) also have chronicled several tragic stories of trafficking of people from their daily livelihood activities in Eritrea's Western Lowland region, including Teseney, Golij and Sawa

${ }^{2}$ Protocol to Prevent, Suppress and Punish Trafficking in Persons Especially Women and Children, supplementing the United Nations Convention against Transnational Organized Crime, UN General Assembly Res. 55/25, Annex II, U.N. GAOR, U.N. Doc. A/45/49 (2001), which entered into force on 25 December 2003. 
Military Camp that involves Eritrean government officials and military personnel targeting mostly people who likely have relatives in the diaspora community. Several testimonies of survivors collected by researchers indicate that they were either lured out from their farming activities under the pretext of job opportunity and cheaper smuggling services to Sudan and handed over to traffickers from Rashaida tribesmen or straight out abducted and driven to Sudan for financial extortion (ibid). Out of whom, many were released after they had paid thousands of dollars ransom money in Sudan, while others were resold to the Bedouin of Sinai for further extortion with no regards for human lives (ibid). But most of the abductions occur from within Shagarab refugee camps and its environs.

As Lijnders and Robinson (2013) has illustrated, '[w] hile crossing the borders to claim asylum may facilitate some protection from abuses perpetrated by the Eritrean government, it has created a new set of challenges for Eritrean refugees who now must find protection and safety from kidnappers' (Lijnders and Robinson 2013:137). As of 2002, the voluntarily smuggling services to seek refuge and protection in Sudan was replaced by a desperate imploration to leave Sudan. This is partly because UNHCR along with the Sudanese government had declared secession clause in 2002 and the insecurity driven by the fear of forced repatriation and deportation to Eritrea has become an imminent threat to most refugees. Largely in response to heightening insecurity in the country of first asylum, a new pattern of secondary migration from Sudan to Libya and from Sudan to Israel through the Saharan and Sinai Deserts had emerged. Although neither the Sinai-Israel nor the Sahara-Libya-Europe smuggling route was common before the UNHCR declaration of cessation clause in Sudan, the Sudan-Libya-Europe route has quickly become a popular escape route for many refugees until 2006 when some Eritreans had increasingly begun to arrive in Israel. Although there is no clear evidence as to the reason for the shift, less distance and cheaper smuggling cost might have played a role. This is because, the SudanLibya-Europe route requires land and maritime smugglers that involve a double financial cost and twice as risky. While there is no record of abduction from Sudan for the purpose of exploitation and extortion in Libya, reselling of refugees and/or subjecting them for cruel violence, rape, detention and extortion during the smuggling process at the hands of smugglers and militias are very common (Al 2015;Gerard, 2014; Van Reisen, et al 2013).

Anyhow, up until 2008, Eritreans had used a voluntary smuggling service to flee Sudan and seek safety, protection and opportunity in Israel and Europe. Since 2008, however, in the face of growing demand for smugglers, the illicit Sudan-Israel trafficking business has become exponentially lucrative and the voluntary 'service providers' have transcended to the highest notoriety of human trafficking practice 'characterized by abduction, displacement, captivity, extortion, torture, sexual violence and humiliation, serial selling and killing....[which]involves the taking of the people against their will or by misleading them and holding them as hostages for ransom or further sale' (Van Reisen, et al 2013:3,23). It is highly likely that the emergence of Sudan-Sinai human trafficking is directly related to the approval of Israeli-Egypt fence construction (which was in mid-2008), the growing xenophobic discourse in Israel and rejection of all Eritrean asylum claims in Israel where the flow had shifted from Sudan-Egypt-Israel to Sudan-Libya-Europe again. The Israeli government has praised the fence for stopping incoming refugees (Rantac 2014), but aggressive and hostile policies towards refugees often tend to shift their direction away from specific country to other countries without having to construct expensive fences. The hostile deterrence strategy recently employed by the Danish Government is a typical example. In November 2014, the Danish Ministry of Justice issued a press release asserting that Eritrean asylum seekers who fled indefinite national service are no longer entitled to refugee status and subsequently, the Eritrean asylum claim in Denmark has dropped from 606 in August 2014 to three in January 2015(Peter 2015). A xenophobic and hostile approach to refugee crisis, however, overburdens other hosts and jeopardizes lives in the process but it doesn't stop refugees from crossing international borders.

By the same token, many Eritreans have begun avoiding Egypt and Israel as early as 2010 and there wasn't as much demand for voluntary smuggling service from Sudan to Israel as there was in the early years of the same decade. Nevertheless, a great number of Eritrean asylum seekers were arriving in Israel to which they had not planned to migrate. Therefore, contrary to a widely held presumption in Israel that asylum-seekers' arrival to Israel were economically motived voluntary movement, research findings show that the vast majority of the Sinai survivors and asylum seekers are bona fide refugees who were coerced and/or tricked by human traffickers mostly with no intention of coming to Israel (Humphris, 2013; Van Reisen et al.2013); some even never heard of the country existed. However, asylum seekers have not been given access to UNHCR asylum procedures, and in the absence of an internationally agreed Refugee Status Determination (RSD) procedures, it would be impossible to determine who is a refugee and who is not. That being said, as the rate of recognition for Eritrean asylum-seekers is around 90 per cent worldwide (UNHCR 2012), there is no valid scientific argument to suggest that only the economic migrants come to Israel. A refugee who is originally a farmer explains that, 'I didn't plan to come to Israel. I hadn't heard of this country when I was in Eritrea. When I crossed the border between Eritrea and Sudan, a soldier caught me and demanded money. I had no money, and that soldier 
transferred me to Bedouin smugglers, who transferred me and many other people to Sinai' (HRM), 2011).

So, many of them were 'either kidnapped (and subsequently sold or surrendered to Bedouins in the Sinai) or smuggled (initially voluntarily, but then sold or surrendered to Bedouins)' (Van Reisen, et al 2013:25). Researchers have estimated that from 2009-2013 around 30,000 refugees were abducted and/or deceived into and trafficked from Eastern Sudan and sold to Egyptian traffickers in the Sinai who have been subjected to humiliating acts of violence and torture to extort ransom money that has increased from $\$ 1,000$ US in 2009 to $\$ 40,000$ US or more in 2013 from their relatives (ibid, 3,61). Besides, paying ransom money doesn't always guarantee their release as the practice involves 'serial selling' and successive extortion' of the victims and 'those who are not able to collect the ransom money are often killed' leading to the deaths of nearly 25 to 50 per cent of the victims (ibid, 24,61,63). In recent years, many tragic stories have been documented and the magnitude of human tragedy and level of human depravity are clearly shown in the number of deaths and testimony of pain. Although some of the refugees were kidnapped and /or lured from Egypt (Cairo), Ethiopia (Mai Aini refugee camp) and Eritrea, the majority of the 'refugees held in the Sinai were kidnapped while in refugee camps or on their way to a family reunion in Sudan...A significant proportion of refugees were kidnapped from within refugee camps [mainly from Shagarab refugee camp] or surrounding areas....'(ibid.25). One of the victims of human traffickers who were kidnapped from Eastern Sudan and held hostage in the Sinai for eight months recounts the barbarity of torture and violence he and others experienced:

They hung me by my arms, and upside down by my ankles. They beat and whipped my back and head with a rubber whip. They beat the soles of my feet with rubber tubes. They put water on my wounds and then beat them. Sometimes they shocked me with electricity, burn me with hot irons, and dripped melted rubber and plastic on my back and arms. They threatened to cut off my fingers using scissors. Sometimes they came into the room, took the women out, and then I heard the women screaming. They came back crying. During the eight months, I saw six others die because of this torture (HRW, 2014a: 33).

In December 24, 2014, the Shagarab refugee camp was assaulted, refugees' huts were torched, and many were kidnapped by a notorious group of human traffickers who belongs to Rashaida ethnic group in collaboration with Sudanese security officials (Awate 2014). In a similar incident, in early June 2015, human traffickers had also 'kidnapped 14 Eritrean asylum seekers out of a lorry rented by UNHCR while transporting them from a nearby refugee camp in eastern Kassala state, a region where human trafficking gangs operate' (Reuters 2015). Due to its clandestine nature, it is difficult to establish a concrete data as to the number of victims of kidnappings, but UNHCR report shows an average of 30 to 50 monthly cases of kidnappings from Eastern Sudan (AI 2013). The UN Monitoring Group on Somalia and Eritrea, US State Department and Human Rights Watch have corroborated the frequent occurrence of refugee abduction from Eastern Sudan where thousands of refugees have been kidnapped from and transport to Sinai where the victims were/are forced to call their family members at home and overseas and have them listen while torturing, raping, and abusing their loved ones on the other end so as they can expedite the money transfer (US Department of State, 2013; HRW, 2014a; UNMGSE 2013). One Eritrean minor who claims to have been abducted and held hostage along with 45 other Eritreans recounts the brutal torture, violence, degrading treatments and rapes by human traffickers:

We were chained to each other with metal chains; about four-five people together. Some of them [human traffickers] forced us to stay completely naked, either standing or sitting... They would only unchain us to torture us like suspend us from the ceiling... Usually, I was beaten with wooden sticks all over the body or with metal wires. Sometimes, they would tie my hands and suspend me from the ceiling for hours. Sometimes, they would also put a wire on my fingers and give me electric shocks. During the torture, they make us call our families... They raped the women in front of us in the same room; it happened almost every day. Some of them [human traffickers] would tell us to look down, while they were doing it (Amnesty International (Al), 2013:13).

In virtually all cases, the practices of violence and despicable abuses endured by thousands of survivors are nearly the same. The vast majority of testimonies are more or less of similar description of the nefarious nature and exploitative activities of the human trafficking operation from and to Eastern Sudan. Be that as it may, the widely held perception about the human trafficking operation from Eastern Sudan to Sinai of Egypt is that it has often been considered criminal activities solely run by private citizens, namely the Rashaida tribesmen (who live in and around the Eritro-Sudan borders) and the Bedouin tribesmen (linguistically and culturally related to Rashaida) in the Sinai. Although the heavy involvements of the aforementioned tribesmen in the trafficking operation is widely reported, the criminal network in this region now incorporates the involvement of different actors in the human trafficking/smuggling chain, including government officials, military personals, police and border guards across multiple borders without which the clandestine criminal operation wouldn't have thrived with impunity.

Besides, there is neither a political will on the part of the receiving countries nor a mechanism in place to protect 
asylum seekers/refugees from risk of being trafficked and provide access to asylum procedures after being trafficked. At times, states have allowed human traffickers to operate with impunity where victims are criminalized and put in prison with no access to asylum systems, while the 'the traffickers are set free and generally left alone to go about their business' (Van et al. 2013:91). Therefore, the political rhetoric and regional attempt to tackle human trafficking has been a failure; because the absence of political will, coupled with corrupt government practices and security forces collusion with traffickers have been some of the contributing factors to the very causes of the transnational criminal network they claim to combat. Survivors' testimonies collected by human rights organizations and academic researchers clearly indicate the involvement of officials in ignoring, tolerating and even participating in human trafficking activities where several refugees were detained by Sudanese police and security forces to only find themselves handed over to human traffickers inside or outside police stations in Eastern Sudan (Lijnders and Robinson, 2013; Rijken, C., Estefanos, M., Van Reisen, M. 2012). One of the survivors reiterates:

Shortly after I crossed into Sudan, two policemen in blue uniforms caught me near Wadi Sherifeh and took me to a police station where they kept me and another Eritrean man from around 6 p.m. to midnight. One of them spoke Tigrinya and told me the police would take me to a nearby refugee camp. Then two policemen drove the two of us for around one and a half hours until we met a pickup truck with four Rashaida in it. They hit us with an iron bar and put us in the back of the pickup and covered us with a big plastic sheet. I then heard them talking with the police for half an hour and then we left and they drove us to a house where they held us for a night before taking us to Egypt (HRW, 2014a: 29).

Many of the refugees were quite aware of the risks of kidnappings in Eastern Sudan before they had left Eritrea. Therefore, some refugees had sought refuge and protection from the Rashaida tribesmen at police stations but little did they know that the police whom they thought were protectors often work in collusion with human traffickers. Although there is no evidence to suggest that Sudan has shown a political willingness to ensure the security of refugees in the camps, to initiate investigation and prosecution of traffickers and corrupt state officials who are involved in the facilitation of trafficking, given Sudan's multiple border entry points and less or no technological surveillance involved, there is a reason to believe that Sudan is not entirely equipped to monitor the criminal operations at the borders. In the case of Egypt, however, the situation is quite different. In principle, the country can control, apprehend and punish traffickers but the willingness to do it in practice seems different story. Regardless from how many directions the human traffickers come, they all cross through the 'heavily policed' Suez Canal either by boats or by cars via the Canal's only bridge for vehicle to reach Sinai (Van Reisen, et al.2013) and hence hard to slip into without the detection and interception of the Egyptian authority. Researchers have reported the involvements of Egyptian police and the military in the facilitation of trafficking and /or turning a blind eye to the activities of the criminal operation (ibid). HRW for instance has documented 19 incidents where:

\begin{abstract}
Sudanese traffickers handed victims over to members of the Egyptian military or police who then transferred them to Egyptian traffickers; at the Suez Canal, where Sudanese or Egyptian traffickers crossing in boats handed victims over to Egyptian soldiers on the eastern (Sinai) side of the canal or where Egyptian policemen on the western side of the canal allowed trucks filled with trafficking victims to cross the canal's only bridge for vehicles; at traffickers' houses or at checkpoints in Sinai, where members of the Egyptian military visited traffickers houses and saw trafficking victims without intervening or where Egyptian military personnel intercepted escaped trafficking victims and returned them to traffickers(HRW, 2014a:42-43).
\end{abstract}

One of the human traffickers interviewed by HRW describes how the police and military collude with their operation at the bridge and/or at the Canal where all the human traffickers routinely drive their buses and truck full of Africans through the tunnel or sail the boats across the bridge:

Until December 2011, all the police at the bridge and tunnel took bribes to let us bring Africans into Sinai. Sometimes the police even drove the trucks across. In December, the military took over control of the bridge. Sometimes they make it difficult to cross at the bridge and tunnel, but they still take bribes and let us cross (ibid, 45-46).

Van Reisen et al. (2013) also described the vulnerability of trafficking victims in Egypt 'as the police ignored potential trafficking-related offences in the Sinai, failed to investigate vehicles used to transport migrants across Ministry of Interior-controlled bridges into the Sinai, and accepted bribes from criminals transporting the migrants and trafficking victims into Sinai' (p.98). The bottom-line is that, human traffickers would not be able to traffic a refugee population of this magnitude through a single bridge or tunnel if it was not for the political unwillingness of the Egyptian government and collusion of corrupt officials with human traffickers. As of now, neither Sudan nor Egypt has investigated, prosecuted or convicted human traffickers and government officials complicit in human trafficking operations. Although Sudan is 
believed to have prosecuted 14 human trafficking cases in Eastern Sudan, out of whom four were police officers (HRW, 2014a), no convictions for the perpetrators and colluders has been reported.

Besides, asylum seekers who are released after ransom payment and/or those managed to escaped from the Sinai torture camps often end up either in Egyptian military prisons with no access to the court of law (contrary to Art. (16)(1) of the 1951 Geneva Convention ${ }^{3}$ to which the country is a signatory) or in Israeli's detention centers and/or face the newly constructed fence, which is designed to deny survivors and other asylum-seekers entry and access to asylum in violation of the Universal Declaration of Human Rights Art14(1). ${ }^{4}$ In Egypt, human trafficking-related crimes have been ignored and contrary to the country's Anti-trafficking law, Art (21) that provides criminal immunity for trafficking victims ${ }^{5}$, survivors are often detained on the grounds of unauthorized entry, which is also contradictory to Art. (31) of the 1951 Refugee Convention ${ }^{6}$ with no access to UNHCR and asylum procedures, medical care and psychosocial assistances(HRW 2014a). As researchers highlighted, traffickers in the Sinai 'seems to be operating under general impunity in which the perpetrators are not prosecuted while the hostages are criminalized' (Van Reisen, et al.2013: 92). If anyone is punished, it is often the victims of human trafficking, not the perpetrators of the crime.

Hundreds of testimonies have vividly described the degrading and inhumane treatments under the human trafficking syndicate and under the Egyptian government but the following testimony has depicted the situation illustratively. After she had endured a grave physical and psychological torture in the Sinai Peninsula, a pregnant woman had given birth in the torture house, and when she was released six months later, she was put in Egyptian prison along with her baby and other survivors awaiting deportations (ibid). As researchers have implied, survivors have been kept imprison for unlimited period of time without due process of the law, and 'the only way to get out of detention in Egypt is by deportation' for which the former human trafficking captives are expected to raise money for their deportation fees (ibid). Although Eritrean refugees are now given an option of getting deported to either Ethiopia or Eritrea, in violation of Art. (33)(1) of the Refugee Convention7, Egypt had previously deported around 1,200 Eritrean refugees back to Eritrea where they had potentially faced persecution in their home country (Esveld, 2008).

In the case of Israel, in addition to the physical barriers erected to push refugees, migrants and trafficked asylumseekers back, in 2012 the country has also introduced an 'Anti-Infiltration Law' which is an amended version of the 1954 Prevention of Infiltration Act (originally designed to combat the infiltration and attacks by Palestinian armed militias) that portrays asylum-seekers as a security threat and indiscriminately labels all migrants, survivors of human trafficking and other asylum seekers as 'Infiltrators'(HRM 2012).The asylum seekers and refugees are placed on the same security continuum as the Palestinian militants. Although the claims of real or perceived security threats posed by refugees in Sudan and Egypt tend to focus on socio-economic and political security, the issue of identity, racial and demographic homogeneity tops the Israeli security concern. As Weiner and Teitelbaum(2001) have noted, '[s]ecurity is a social construct with different meanings in different societies. An ethnically homogenous society, for example, may place higher value in preserving its ethnic character than a heterogeneous society and may, therefore, regard population influx as a threat to its security' (Weiner and Teitelbaum, 2011:112-114). Hence, a xenophobic discourse and progressive demonization and criminalization of African refugees have become the core political strategy of promoting and maintaining the demographic, socio-cultural and racial homogeneity of Israel under the pretext of national security. After Eli Yishai (then Interior Minister) had previously incited a xenophobic and parochial political statement to make their lives miserable, Benjamin Netanyu, the Prime Minster of Israel has also asserted that 'illegal infiltrators [who are] flooding the country [are] threaten[ing] the social fabric of society, our national security, our national identity...and ...our existence as a

${ }^{3}$ Article (16)(1) of the 1951 Geneva Convention states that a refugee shall have a free access to the courts of law on the territory of all Contracting States

${ }^{4}$ Article 14(1) of the Universal Declaration of Human Rights states that 'Everyone has the right to seek and to enjoy in other countries asylum from persecution.'

${ }^{5}$ Egypt's Anti-trafficking law, Bill 64/2010, Article (21) states that, 'the victim shall not be criminally or civilly liable for any of the crimes of human trafficking as long as the crime occurred or was directly related to being a victim.'

${ }^{6}$ Article 31 of the 1951 Geneva Convention states that the Contracting States shall not impose penalties, on account of their illegal entry or presence, on refugees, who, coming directly from a territory where their life or freedom was threatened in the sense of Article 1, enter or are present in their territory without authorization, provided they present themselves without delay to the authorities and show good cause for their illegal entry or presence.

${ }^{7}$ Article (33)(1) of the 1951 Geneva Convention reiterates that "No Contracting State shall expel or return (" refouler ") a refugee in any manner whatsoever to the frontiers of territories where his life or freedom would be threatened on account of his race, religion, nationality, membership of a particular social group or political opinion.' 
Jewish and democratic state' (Rosenberg, 2014).

Consequently, all African asylum seekers, including survivors of human trafficking are portrayed as 'security threat' and are equally liable to punishment by mandatory imprisonment upon arrival. After fleeing persecutions and deathdefying flight experiences at home and transits, they are exempted neither from the 'Anti-Infiltration' law nor offered a psychosocial and health support by the country of destination. The law was set to accomplish at least four objectives: (a) to establish a legal ground to avoid moral and legal responsibility to protect and provide refugees with access to rights and entitlements; (b) to define asylum seekers as criminals and authorize the authorities to detain asylum seekers for the crime of 'infiltration' up to three or more years without due process of law (Hotline For Refugees and Migrants (HRM), 2014a), which infringes the right to liberty and dignity of person enshrined in Art.(5) of Israel's Basic Law, and in contravention of Art. (9)(1)(3) of the International Covenant on Civil and Political Rights (ICCPR) (to which Israel is also a party); (c) to send a message of deterrence to potential incoming asylum seekers, and to finally ensure that those already in the country are miserable and despaired enough that they can 'voluntarily' depart. The law has since then been amended twice leading to the 2014 version where new arrivals are detained for three months in prison without trial before transferred to Holot Residency Center (an open detention center managed by the Israeli Prison Services) where they would stay there for 20 months 'until they can be deported-until the political situation in their countries of origin improves, or until they succumb to the pressure and "agree" to sign documents declaring that they are "voluntarily" returning to their homeland' (HRM 2014b). Pursuant to the new law, all African asylum seekers in Israel are required to live in or report to the 'Residency Center' as of December 2014(HRW, 2014b).

The country has been trumpeting to offer potential deportees up to 3,500 \$ US dollars contingent upon their agreement to leave 'voluntarily' (Fezehai, 2015). Although Eritrean asylum seekers have not been deported to their country of origin, unable to secure refugee status, frustrated by the limbo of illegality and the uncertainty of future security prospects, and by the continuity of constant detention or threat of detention, several Eritrean asylum seekers have selfdeported to Rwanda and Uganda where they have also been denied asylum procedure (HRW 2014b) and thus triggered another cycle of smuggling process which involves secondary victimization of victims of human trafficking en the route to Europe. Out of the deportees, 12 are believed to have lost their lives in the 2013 Lampedusa tragedy in the Mediterranean Sea and three were killed by Islamic State militants in Libya in 2015 (Booth, 2015). Besides, out of the 34,000-40,000 Eritrean asylum seekers who managed to enter Israel mostly before the construction of the fence and before the introduction of the Infiltration Law may not mostly be in official prisons but only four have been recognized as refugees (Tsurkov, 2015). The rest of them are living either on the hard-to-renew temporary permit or 'conditional release' (2A5) with no access to civil liberty and to 'formal work permits, the national health care system and social services' (Schwartz, 2015; HRW 2014b) and liable to detention upon the expiry of the permit.

In sum, all the three States are the signatories of the 1951 Refugee Convention and 1967 Protocol relating to the Status of Refugee and they have fundamental responsibilities to protecting vulnerable refugees and asylum seekers who are in their jurisdictions. However, one can argue that the lack of compassion, rejection of asylum seekers, inaction against human traffickers, and the disregards for the kidnappings, abuse and humiliation of refugees in broad daylight, sometimes by law and border enforcements personnel could be translated into a deliberate policy to make their transit route and destination sufficiently miserable to serve as a deterrent element to others from coming to their countries and push out those who are already in their territories. Therefore, it is fair to say that all cases are examples 'par excellence' of a deliberate failure and breach of international human rights and refugee laws, which have maximized human tragedy and created fertile grounds for human traffickers who inherently benefit from the exploitation and victimization of the unprotected and the vulnerable human beings.

\section{Conclusion}

Human trafficking is a transnational crime and it takes political willingness, commitment and collaboration at national, regional and transnational levels where the needs and fundamental rights of asylum seekers and survivors should be at

${ }^{8}$ Art (5) of Israel's Basic Law: Human Dignity and Liberty states that 'There shall be no deprivation or restriction of the liberty of a person by imprisonment, arrest, extradition or otherwise.'Article (9)(1) of the ICCPR also states that 'Everyone has the right to liberty and security of person. No one shall be subjected to arbitrary arrest or detention. No one shall be deprived of his liberty except on such grounds and in accordance with such procedure as are established by law.' Sub-article (3) also states that 'Anyone arrested or detained on a criminal charge shall be brought promptly before a judge or other officer authorized by law to exercise judicial power and shall be entitled to trial within a reasonable time or to release...' 
the center of prevention efforts, protection of victims and prosecution of the perpetrators. The first step to prevent human trafficking is to eliminate the root of the problem at the source country in terms of human insecurity, which are some of the driving forces behind the growing desire to leave and the rise of the organized crime syndicate who benefit from people's socio-economic and political despair.

In addition to implementing legislative measures to prosecute traffickers and colluders and ensuring the security and protection of the displaced populations, transit and destination countries should adopt victim-centered approach in terms of providing survivors with psychosocial, physical and material assistance as well as access to judicial and asylum procedures consistent with the international human rights and refugee laws. Be it temporary or permanent, asylum seekers and survivors of human trafficking deserve protection, assistance and permission to remain legally in the hosts' territories, not punishment, rejection, imprisonment and deportation just for a sole reason of entry and asylum seeking. Besides, the profit-motivated human smugglers can partially be driven out of the market by opening up a legal immigration channels, flexible migration policies, reintroduction of quota system and responsibility-sharing. As an indiscriminate legalization of human smuggling would be as dangerous as over-criminalizing them, governments will have to follow the Canadian lead in decriminalizing altruistic smugglers and providing compassionate conditions to vulnerable asylum seekers who need protection. ${ }^{9}$

\section{References}

Adepoju, A.(2005). 'Review of Research and Data on Human Trafficking in Sub-Sab-Saharan African.' International Migration Vol.43, No.1/2, Blackwell Publishing Ltd.

Amnesty International (AI)(2013). 'Egypt/Sudan: Refugees and Asylum-seekers face brutal treatment, kidnapping and for ransom, and human trafficking.' Index: AFR 04/001/2013

Amnesty International (AI) (2015). "Libya is full of cruelty"' Stories of abductions, sexual violence and abductions from migrants and refugees.' Index: MDE 19/1578/2015.

Awate.com(December 28,2014). 'Who Will Speak for the Voiceless Eritreans In Sudan?' http://awate.com/who-will-speak-for-thevoiceless-eritreans-in-sudan/ [Accessed: May 12, 2015]

Aronowitz, A.(2001).'Smuggling and trafficking in human beings: the phenomenon, the markets that drive it and the organizations that promote it.' European Journal on Criminal Policy and Research, Vol. 9, No. 2.

Black, R.(2003). Breaking the Convention: Researching the "Illegal" Migration of refugees to Europe.' Sussex Center for Migration Research, University of Sussex. Blackwell Publishing.

Booth, W.(2015, May 14).'Israeli government to refugees: Go back to Africa or go to prison.' The Washington Post. https://www.washingtonpost.com/world/middle_east/toughening-its-stance-toward-migrants-israel-pushes-africans-to-leave/2015 /05/14/e1637bce-f350-11e4-bca5-21b51bbdf93e_story.html [Accessed: March 10,2015].

Chuang, J.(2006). 'Beyond a Snapshot: Preventing Human Trafficking in the Global Economy.' Indiana journal of global legal studies, Vol.13, issue 1.

Crépeau, F. (2013). 'Mainstreaming a human rights-based approach to migration within the High Level Dialogue.' Statement by the UN Special Rapporteur on the human rights of migrants, PGA Plenary Session - Criminalization of Migrants

Delport, E., Koen, K., and Mackay, A.(2007).'Human Trafficking in South Africa: Root Causes and Recommendations.' UNESCO Policy Paper No.14.5 (e). SHS/CCT/2007/PI/H/6.

European Union Commission (2015). 'EU announces support for poverty eradication in Eritrea' [Press Release]. http://europa.eu/rapid/ press-release_IP-15-6298_en.htm_[Accessed: December 25,2015]

Friesendorf, C.(ed)(2009). 'Strategies Against Human Trafficking: The Role of the Security Sector.' Geneva Centre for the Democratic Control of Armed Forces (DCAF).

Esveld, B.(2008). Sinai Perils: Risks to Migrants, Refugees, and Asylum Seekers in Egypt and Israel. Human Rights Watch.

Fezehai,M.(October 31,2015). 'Israel's Chilly Reception of African Asylum Seekers.' The New York Times. http://www.nytimes. com/interactive/2015/10/31/opinion/sunday/exposures-israel-chilly-reception-for-african-asylum-seekers.html?_r=0 [Accessed: December 16, 2015]

Gallagher, A.(2001). Human Rights and the New UN Protocols on Trafficking and Migrant Smuggling: Preliminary Analysis.' Human Rights Quarterly, Vol.23, No.4. Johns Hopkins University Press.

Gerver, M.(2015). 'Why the EU should consider decriminalizing people smuggling.' The London School of Economics and Political Science(LSE).http://blogs.Ise.ac.uk/europpblog/2015/09/16/why-the-eu-should-consider-decriminalising-people-smuggling/ [Accessed: January 6, 2016].

Gerard, A.(2014). The Securitization of Migration and Refugee Women. Routledge Studies in Criminal Justice, Borders and Citizenships

${ }^{9}$ R. v. Appulonappa, 59 Supreme Court of Canada (SCC)(2015). Under Canadian new law, it is not a crime to assist refugees reach safety and hence people who support others in the flight to safety are not subjected to prosecution. 
Hathaway, James (2008). 'The Human Rights Quagmire of "Human Trafficking."' Virginia Journal of International Law, Vol.49, no.1.

Hotline for Refugees and Migrants (HRM)(2012). 'Legislation Targeting Asylum Seekers in Israel in 2012.' http://hotline.org.il/wpcontent/uploads/HotlineReport080812LegislationEng.pdf [Accessed: July 10, 2015].

Hotline for Refugees and Migrants (HRM)(2011). 'The Dead of the Wilderness' Testimonies from Sinai Desert. http://www.everyone group.com/downloads/ReportDecember2010.pdf [Accessed: July 9, 2015].

Hotline For Refugees and Migrants(HRM) (April 1,2014). 'Detention of Asylum-Seekers in Israel.' http://www.americanbar.org/content/ dam/aba/events/labor_law/2014/05/international-labor-and-employment-law-committee-midyear-meeting/michaeli4.authcheck dam.pdf [Accessed: Jüne 15, 2015]

Hotline For Refugees and Migrants(HRM) (2014). 'Anti-Infiltration Law.' http://hotline.org.il/en/refugees-and-asylum-seekers-en/\%E2 \%80\%8Fdetention-of-asylum- seekers/ [Accessed: June 15, 2015]

Human Rights Watch (RW) (2015). 'The Mediterranean Migration Crisis: Why People Flee, What the EU Should Do.'

Human Rights Watch(HRW)(2014). "Make Their Lives Miserable" Israel's Coercion of Eritrean and Sudanese Asylum Seekers to Leave Israel.'

Human Rights Watch (HRW)(2014). "'I want to Lie Down and Die." Trafficking and Torture of Eritreans in Sudan and Egypt.'

Humphris, R.(2013). 'Refugees and the Rashaida: human smuggling and trafficking from Eritrea to Sudan and Egypt.' UNHCR Policy Development and Evaluation Service, Research Paper No. 254.

Kanter, J (May 18, 2015). 'E.U. Agrees to Naval Intervention on Migrant Smugglers.' The New York Times. http://www.nytimes.com/ 2015/05/19/world/europe/european-union-human-trafficking-military.html?_r=0 [[Accessed: July 12, 2015]

Lijnders, L. and Robinson, S. (2013). 'From the Horn of Africa to the Middle East: Human trafficking of Eritrean asylum seekers across borders.'Anti-trafficking Review, No.2.

Nichols, M. and Charbonneau, L.(19 Oct, 2015). 'U.N. council OKs mission against human trafficking off.' Reuters.com. http://www.reuters.com/article/us-europe-migrants-un-idUSKCNOS31PJ20151009 [Accessed: January 11, 2016]

Peter, S.(2015). 'Eritrean Lives Risked in Civil Service Scandal.' The Murmur. http://murmur.dk/articles/eritrean-lives-risked-in-civilservice-scandal.373.html [Accessed: December 29, 2015]

Rantac, J. (25 Mar 2014). "Israel's Two-Step Solution to African 'Infiltrators.' International Policy Digest. [Accessed: July 16, 2015], http://www.internationalpolicydigest.org/2014/03/25/israels-two-step-solution-african-infiltrators/

Rijken, C., Estefanos, M., Van Reisen, M, (2012). 'Human Trafficking in the Sinai: Refugees between life and death', Tilburg University, EEPA, Brussels.

Reuters (June 4, 2015). 'Fourteen Eritrean asylum seekers kidnapped in Sudan - UNHCR source.' http://www.trust.org/item/2015060 4201829-tt9ph/?source=leadCarousel_[Accessed: July 18, 2015]

Rosenberg , D.( September 11,2014). 'How to solve the African migrant 'threat' and do the right thing, too.' http://www.haaretz. com/misc/iphone-article/.premium-1.615269 [Accessed: October 17, 2015]

Schwartz, Y.(Oct 13, 2015). 'Non-Jewish Refugees Get a Cold Shoulder in Israel.' The newsweek.com, http://www.newsweek.com/ 2015/10/23/what-europe-can-learn-israels-refugee-crisis-382523.html. Accessed: December 2, 2015]

Tsurkov, E. (November 18,2015). 'Israel's Deportation Policy Forces Asylum Seekers to Choose Between Prison and Persecution.' Newsweek.com. http://www.newsweek.com/israels-deportation-policy-forces-asylum-seekers-choose-between-prison-and-3959 21 [Accessed: December 1, 2015]

Van Reisen, et al. (2013). 'The Human Trafficking Cycle: Sinai and Beyond.' Wolf Legal Publishers(WLP), Oisterwijk.

UN High Commissioner for Refugees (UNHCR)(2013). 'UNHCR concern at refugee kidnappings, disappearances in eastern Sudan.'

UN High Commissioner for Refugees (UNHCR) (2012). 'Displacement: The New 21 st Century Challenge.' UNHCR Global Trends 2012.

United Nations Security Council (2012). Monitoring Group on Somalia and Eritrea pursuant to Security Council resolution 2060.

United Nations Office on Drugs and Crime (UNODC)(2016). 'Human Trafficking.' https://www.unodc.org/unodc/en/human-trafficking/ what-is-human-trafficking.html [Accessed: January 16, 2016]

United Nations Security Council (2012). Monitoring Group on Somalia and Eritrea(UNMGSE) pursuant to Security Council resolution 2060, (Annex 2.2)

United States Department of State (2013). 'Trafficking in Person Report 2013,'

Webb, S. and Burrows, J.(2009). 'Organized Immigration Crime: A Post-Conviction Study.' Research Report No. 15, UK Home Office. Weiner, M and Teitelbaum, M. (2001). Political Demography, Demographic Engineering. Berghahn books, U.S.A.

Zhang, Sheldon, X.(2007).Smuggling and Trafficking in Human Beings: All Roads Lead to America. Praeger Publisher. 
